\title{
Variability in Sr:Ca and Ba:Ca ratios in water and fish otoliths across an estuarine salinity gradient
}

\author{
Jed I. Macdonald*, David A. Crook \\ Arthur Rylah Institute for Environmental Research, 123 Brown Street, Heidelberg 3084, Australia
}

\begin{abstract}
Retracing movements of euryhaline fishes using otolith chemistry analysis is a complex task, requiring detailed knowledge of the relationships between otolith and water chemistry for the target species and how these relationships change across dynamic environmental gradients in estuaries. In a controlled laboratory experiment, we quantified relationships between salinity and $\mathrm{Sr}: \mathrm{Ca}$ and Ba:Ca ratios in ambient water and otoliths in euryhaline Australian bass Macquaria novemaculeata across a salinity gradient encompassing freshwater to marine values (i.e. 0.5, 5, 21 and $38 \%$ ). Results from the laboratory experiments in addition to analyses of water samples from 7 coastal rivers in Victoria, Australia, showed consistent positive $(\mathrm{Sr}: \mathrm{Ca})$ and negative $(\mathrm{Ba}: \mathrm{Ca})$ non-linear relationships between salinity and otolith/water chemistry, with the greatest change in elemental concentrations occurring at $<5 \%$. Otolith $\mathrm{Sr}$ :Ca increased linearly with ambient values, while otolith $\mathrm{Ba}$ :Ca increased exponentially. Uptake of $\mathrm{Sr}$ and Ba into the otoliths varied with salinity, with partition coefficients $\left(D_{\mathrm{Sr}}\right.$ and $\left.D_{\mathrm{Ba}}\right)$ maximised at the lowest and highest salinities, respectively. Otolith transects revealed high individual variability in the timing and magnitude of $\mathrm{Sr}: \mathrm{Ca}$ and $\mathrm{Ba}: \mathrm{Ca}$ responses following transfer of bass from higher salinities to the lowest salinity $(0.5 \%)$. Substantial time-lags in elemental uptake were also evident, with $\mathrm{Sr}$ :Ca taking $\leq 40 \mathrm{~d}$ and $\mathrm{Ba}: \mathrm{Ca} \leq 30 \mathrm{~d}$ for concentrations to reach equilibrium at $0.5 \%$. Whilst otolith $\mathrm{Sr}: \mathrm{Ca}$ and $\mathrm{Ba}: \mathrm{Ca}$ are clearly useful as indicators of movement across coarse salinity gradients, our data suggest that the addition of alternative chemical markers to augment measurement of trace element concentrations is needed to improve resolution at finer scales.
\end{abstract}

KEY WORDS: Australian bass $\cdot$ Macquaria novemaculeata $\cdot$ Estuary $\cdot$ Otolith chemistry $\cdot$ Salinity · $\mathrm{Sr}: \mathrm{Ca} \cdot \mathrm{Ba}: \mathrm{Ca}$

Resale or republication not permitted without written consent of the publisher

\section{INTRODUCTION}

The ability to accurately trace movements of euryhaline fishes is critical to understanding their dispersal and migration patterns across freshwater, estuarine and marine interfaces. Whilst much information has been gained through traditional tagging and telemetry studies (e.g. Hindell et al. 2008, Luo et al. 2009), analysis of the chemistry of calcified structures, particularly otoliths, which can reflect environmental changes experienced by fish throughout life, has become increasingly widespread in recent years (see review by Gillanders 2005). Otoliths grow continuously throughout the life of the fish, forming daily and annual growth bands, and are composed of a calcium carbonate lat- tice that is not re-metabolised once deposited (Campana \& Neilson 1985, Campana 1999). These 2 properties-combined with strong evidence that certain trace elements (e.g. Sr and Ba) are incorporated into otoliths in proportion with ambient water concentrations (Bath et al. 2000, Wells et al. 2003, Elsdon \& Gillanders 2003, 2005a), which in turn can reflect salinity and temperature gradients (Zimmerman 2005, Martin \& Wuenschel 2006) — make otoliths potentially useful as environmental recorders.

With rapid improvements in our understanding of the pathways by which elements are incorporated into otoliths and in the analytical capabilities of sampling equipment, researchers are now able to trace movement histories of individuals and connections among 
populations at increasingly fine scales (Swearer et al. 1999, Kennedy et al. 2000, Elsdon \& Gillanders 2005b, Weidel et al. 2007). In complex and dynamic environments such as estuaries, however, movements by fish commonly occur across gradients of water chemistry, temperature and salinity that may vary spatially over time frames as short as a tidal cycle (Dorval \& Jones 2005, Elsdon \& Gillanders 2006). Furthermore, factors such as the extent of tidal ingress, the level of mixing of fluvial and marine particulates, the vertical and longitudinal location of the salt wedge, anoxia and watershed runoff can markedly influence both distribution patterns of fish (e.g. Brenner \& Krumme 2007, Nicholson et al. 2008) and the distribution and abundance of trace elements throughout estuaries (Turner et al. 1981, Zwolsman \& van Eck 1999). This complexity poses substantial challenges for those aiming to reconstruct environmental histories of fish in these systems based on otolith chemistry data.

A number of studies have used controlled laboratory or field experiments to assess the relationships between environmental variables and otolith elemental concentrations across salinity gradients (e.g. Bath et al. 2000, Elsdon \& Gillanders 2002, 2004, Kraus \& Secor 2004, Zimmerman 2005, Martin \& Wuenschel 2006, Donohoe et al. 2008). Such experiments provide important information for the interpretation of otolith chemistry data from wild-caught fish, although they do not replicate the full scale of physical and chemical variability that occurs in many estuaries. Most studies have reported a strong positive relationship between otolith Sr:Ca and ambient water Sr:Ca (Bath et al. 2000, Elsdon \& Gillanders 2003) and a generally positive association between water Sr:Ca and salinity (see Secor \& Rooker 2000 for review, Zimmerman 2005). However, salinity may not always correlate positively with water or otolith Sr:Ca concentrations, particularly in moderate to high salinity environments (e.g. Elsdon \& Gillanders 2002, Kraus \& Secor 2004, Dorval et al. 2007), and freshwater Sr:Ca values have been shown to exceed marine Sr:Ca in some cases (Kraus \& Secor 2004). Furthermore, Sr:Ca in water and otoliths has been shown to vary with temperature (Martin et al. 2004) or interactively with temperature and salinity (Elsdon \& Gillanders 2002, 2004, Martin \& Wuenschel 2006). Consequently, good knowledge of the relationships between water $\mathrm{Sr}: \mathrm{Ca}$, salinity and temperature in the study system and their respective effects on otolith $\mathrm{Sr}: \mathrm{Ca}$ are required when using $\mathrm{Sr}: \mathrm{Ca}$ alone to trace salinity histories of wild-caught fish.

The consistent increase in otolith $\mathrm{Ba}: \mathrm{Ca}$ with water Ba:Ca (e.g. Bath et al. 2000, Wells et al. 2003), the predictable decrease in water $\mathrm{Ba}$ :Ca with increased salinity (e.g. Elsdon \& Gillanders 2005b,c, Dorval et al. 2007) and large differences in Ba:Ca concentrations between fresh and marine waters can provide additional inference for tracing movements of fishes across the freshwater-saltwater interface. Increasingly, studies are incorporating measurement of $\mathrm{Ba} \mathrm{Ca}$ in conjunction with Sr:Ca (Crook et al. 2006, Hale \& Swearer 2008) and/or other isotope ratios (e.g. $\mathrm{Sr}^{87}: \mathrm{Sr}^{86}$; McCulloch et al. 2005, Milton et al. 2008) in order to examine movement across salinity gradients. However, recent work has shown notable complexity in $\mathrm{Ba}$ :Ca across otolith transects that can be difficult to interpret based on ambient Ba:Ca or salinity gradients (e.g. Elsdon \& Gillanders 2005b, Crook et al. 2006, Milton et al. 2008). Such complexity might be explained by facilitation or competition in uptake between trace metals (de Vries et al. 2005) or physiological, age- or growth-related factors (Kalish 1989, 1991).

The rate of uptake of particular elements into otoliths also warrants careful consideration. Otoliths are not in direct contact with the surrounding water, and the incorporation of ions from water to blood to endolymph to otolith is regulated by physical and physiological filters operating across branchial, intestinal and saccular epithelia (Campana 1999, Payan et al. 1999, 2002). These barriers commonly result in discrimination in elemental uptake, with lower concentrations reported in otoliths relative to the surrounding water concentrations (e.g. Elsdon \& Gillanders 2003, Martin \& Wuenschel 2006), although uptake of Sr and Ba above ambient levels has also been shown (Elsdon \& Gillanders 2005a). The presence of physiological filters means that changes in environmental variables that affect otolith chemistry may not immediately be reflected in the otolith, but are subject to a time lag. Elsdon \& Gillanders (2005c) demonstrated that $\sim 20$ d of exposure to stable environmental conditions was required before Sr:Ca in otoliths of juvenile black bream Acanthopagrus butcheri reached equilibrium. Similarly, laboratory results for juvenile largemouth bass Micropterus salmoides showed that approximately $21 \mathrm{~d}$ was needed for otolith $\mathrm{Sr}$ :Ca to reach a saturation level at salinities of 5 or $10 \%$ (Lowe et al. 2009). Hence, for species that undertake rapid movements between different chemical environments or across salinity gradients, a delay in uptake of any elements used to trace movements limits the spatial and temporal resolution achievable.

The present study addressed these issues by examining the response of $\mathrm{Sr}: \mathrm{Ca}$ and $\mathrm{Ba}: \mathrm{Ca}$ in otoliths of the euryhaline Australian bass Macquaria novemaculeata to the range of salinities typically encountered by the species in estuaries. Our specific aims were to (1) use controlled experiments to quantify relationships between salinity and $\mathrm{Sr}: \mathrm{Ca}$ and $\mathrm{Ba}: \mathrm{Ca}$ ratios in water and otoliths across a salinity gradient encompassing freshwater to marine values, (2) examine time lags in the 
uptake of $\mathrm{Sr}: \mathrm{Ca}$ and Ba:Ca following changes in salinity, and (3) compare relationships between salinity and ambient Sr:Ca and Ba:Ca derived from the laboratory experiments with results from water samples collected from coastal rivers in southern Victoria, Australia. The nature and consistency of these relationships are discussed in terms of the implications for reconstructing movements of euryhaline fishes using otolith chemistry.

\section{MATERIALS AND METHODS}

Study species. The Australian bass Macquaria novemaculeata (hereafter referred to as bass), a catadromous member of the family Percichthyidae, is widely distributed across coastal drainages in southeastern Australia and is an important recreational angling species. Adults of the species are thought to remain in freshwater reaches for most of the year, with a downstream migration taken to the estuary during winter to spawn (Harris 1986). Spawning occurs at salinities of $>8$ to $10 \%$ in estuaries, but has been observed in waters up to $35 \%$ in culture (Battaglene \& Selosse 1996), and eggs hatch after $42 \mathrm{~h}$ under optimal conditions (i.e. 25 to $35 \%$, $18^{\circ} \mathrm{C}$; van der Wal 1985). Relatively little is known of the development and movements of larvae and juveniles in the wild. Larvae can tolerate seawater-level salinity in captivity (Battaglene \& Selosse 1996, authors' unpubl. data) and there is evidence that at least some individuals spend time at sea during the early larval phase prior to movement back into estuaries (Trnski et al. 2005). Adults have also been captured in 11 to $17 \mathrm{~m}$ of water in trawls off the coast of central New South Wales, Australia (Trnski et al. 2005), suggesting that marine residency by some adults may occur at least for short periods.

Laboratory experiments. Juvenile (42 d old) bass were sourced from the RMIT University Marine Research facility at Lakes Entrance, Victoria, on 20 Sep- tember 2006. During the first 6 wk of life, the fish were housed in $1000 \mathrm{l}$ tanks held at a constant $16^{\circ} \mathrm{C}$ and $27 \%$. Approximately 50 fish were transported to the aquarium facility at the Arthur Rylah Institute for Environmental Research (ARI) and kept in the original hatchery water for $8 \mathrm{~d}$. During this period fish were fed daily with rotifers Brachionus plicatilis.

To examine the response of $\mathrm{Sr}: \mathrm{Ca}$ and $\mathrm{Ba}: \mathrm{Ca}$ in bass otoliths to changes in salinity, 3 experimental salinity treatments $(5,20$ and $38 \%$ ) were selected to reflect the likely range of salinities in estuaries. A total of $200 \mathrm{l}$ of full-strength seawater (38\%) was collected from Seaspray Beach $\left(38^{\circ} 22^{\prime} \mathrm{S}, 147^{\circ} 27^{\prime} \mathrm{E}\right)$ on 25 September 2006 and transported immediately to the ARI aquarium. Upon arrival, 1001 of the water was separated and diluted with ARI aquarium water $(0.5 \%$ ) to 5 and $21 \%$, while the remaining $100 \mathrm{l}$ was maintained at $38 \%$. After $8 d$, fish were randomly allocated to one of six 201 aerated glass tanks containing the 3 salinity treatments, with 2 replicate tanks per treatment (Table 1). Fish were maintained in static water under these conditions for $72 \mathrm{~d}$. Salinity levels and water temperatures in each tank were recorded every second day and kept constant throughout the experimental period (Table 1). A one-third volume water change using aquarium water and seawater collected from Seaspray Beach was conducted every 2 to $3 \mathrm{~d}$ to remove waste and detritus and maintain water quality. All fish were fed daily with equal amounts of Artemia sp. nauplii.

On Day 72 of the experiment, all fish from Tanks 1, 3 and 5 were removed from their tanks, killed by immersion in an ice slurry, measured for total length (TL, $\pm 1 \mathrm{~mm}$ ) and kept frozen. At this time, all fish from Tanks 2, 4 and 6 were also removed, measured for TL and immersed in a $0.025 \%$ alizarin red S (ARS) solution for 10 min to provide an otolith mark (Crook et al. 2007), before being transferred to $1000 \mathrm{l}$ tanks each filled with ARI aquarium water $(0.5 \%)$. This provided a fourth salinity treatment of $0.5 \%$, representing typical

Table 1. Macquaria novemaculeata. Summary of fish numbers (n), total length (TL) after 72 and 122 d and experimental conditions in each tank. Data are means \pm SE. For salinity and temperature data, the number of measurements upon which means are calculated is shown in parentheses. Blank cells: not applicable

\begin{tabular}{|c|c|c|c|c|c|c|}
\hline \multirow{2}{*}{$\begin{array}{l}\text { Salinity treat- } \\
\text { ment }(\% \circ)\end{array}$} & \multirow[t]{2}{*}{ Tank } & \multirow[t]{2}{*}{$\mathrm{n}$} & \multicolumn{2}{|c|}{ TL (mm) } & \multirow[t]{2}{*}{ Salinity $(\%$ o) } & \multirow[t]{2}{*}{ Temperature $\left({ }^{\circ} \mathrm{C}\right)$} \\
\hline & & & $72 \mathrm{~d}$ & $122 \mathrm{~d}$ & & \\
\hline \multirow[t]{2}{*}{5} & 1 & 5 & $17.8 \pm 0.37$ & & $5.55 \pm 0.09(28)$ & $20.81 \pm 0.1(28)$ \\
\hline & 2 & 6 & $17.71 \pm 0.42$ & & $5.54 \pm 0.09(28)$ & $20.78 \pm 0.09(28$ \\
\hline \multirow[t]{2}{*}{21} & 3 & 6 & $17.67 \pm 0.42$ & & $21.55 \pm 0.13(28)$ & $20.79 \pm 0.1(28)$ \\
\hline & 4 & 7 & $17.86 \pm 0.46$ & & $21.43 \pm 0.11(28)$ & $20.76 \pm 0.09(28$ \\
\hline \multirow[t]{2}{*}{38} & 5 & 5 & $17.8 \pm 0.2$ & & $38.18 \pm 0.24(28)$ & $20.84 \pm 0.1(28)$ \\
\hline & 6 & 7 & $17.16 \pm 0.7$ & & $38.19 \pm 0.33(28)$ & $20.80 \pm 0.1(28)$ \\
\hline \multirow[t]{3}{*}{0.5} & 7 & 6 & $17.71 \pm 0.42$ & $20.86 \pm 0.34$ & $0.5 \pm 0.004(22)$ & $20.75 \pm 0.04(22$ \\
\hline & 8 & 7 & $17.86 \pm 0.46$ & $21.0 \pm 0.31$ & $0.5 \pm 0.004(22)$ & $20.75 \pm 0.04(22$ \\
\hline & 9 & 7 & $17.16 \pm 0.7$ & $20.67 \pm 0.49$ & $0.5 \pm 0.004(22)$ & $20.75 \pm 0.04(22$ \\
\hline
\end{tabular}


salinities experienced by bass living in freshwater. These tanks (Tanks 7, 8 and 9; Table 1) were maintained on a recirculation system fed by the same water source used to dilute the seawater, with fish taken from a particular salinity treatment allocated a tank containing only fish from that treatment. Fish were held under these conditions for a further $50 \mathrm{~d}$ with the feeding regime kept constant. Fish were then killed by immersion in an ice-slurry, measured for TL and frozen as before (Table 1).

Otolith preparation and analysis. Sagittal otoliths from all frozen samples were dissected under a stereo microscope, cleaned of adhering tissue, rinsed in Milli$\mathrm{Q}$ water (Millipore) and stored dry in $0.5 \mathrm{ml}$ polypropylene microtubes. One sagitta from each fish was mounted whole (proximal surface downwards) on a glass slide in thermoplastic glue (Crystalbond ${ }^{\mathrm{TM}}$ ), then polished to the level of the primordium using 5 and $3 \mu \mathrm{m}$ lapping films and $0.5 \mu \mathrm{m}$ alumina slurry. The samples were then rinsed in Milli-Q water and airdried overnight in a class 100 laminar flow cabinet at room temperature.

Otoliths were analysed using laser ablation-inductively coupled plasma-mass spectrometry (LA-ICP-MS). We used a Resonetics LPX120i ArF 193 nm excimer laser system (Resonetics) coupled to an Agilent 7500s ICP-MS (Agilent Technologies) located at Australian National University, Canberra, Australia. The procedures for transect analysis followed those of Crook et al. (2008) with some minor modifications. Briefly, slides were placed in the sample cell and the otoliths visualised with a $400 \times$ objective lens and a video imaging system. Each otolith was ablated along a transect from the ventral to the dorsal margin through the core using a $6 \times 100 \mu \mathrm{m}$ rectangular ablation slit (see Fig. 1). The laser was operated at $120 \mathrm{~mJ}$ energy and pulsed at $10 \mathrm{~Hz}$ with a scan rate of $\sim 2 \mu \mathrm{m} \mathrm{s}^{-1}$, resulting in an ablation depth of $\sim 3 \mu \mathrm{m}$ along the transects. The otoliths were analysed for several elements including ${ }^{43} \mathrm{Ca},{ }^{55} \mathrm{Mn},{ }^{88} \mathrm{Sr}$ and ${ }^{138} \mathrm{Ba}$, and $\mathrm{Ca}$ was measured for use as an internal standard to correct for variation in ablation yield among samples. Data reduction and processing was done offline using Excel spreadsheets. To reduce the noise along transects, raw counts for $\mathrm{Mn}$, $\mathrm{Sr}, \mathrm{Ba}$ and $\mathrm{Ca}$ were averaged using a 9-point running mean, and then further smoothed using a 9-point running median (Sinclair et al. 1998). This was followed by subtraction of background ion counts from otolith counts and normalisation of each element to ${ }^{43} \mathrm{Ca}$ using an external calibration standard (National Institute of Standards Technology, NIST 612) which was analysed after every 10 otolith samples. Data from each otolith were expressed as element:Ca ratios (i.e. Sr:Ca, Ba:Ca). Measurement precision (\% relative standard deviation [RSD]) was determined based on analyses
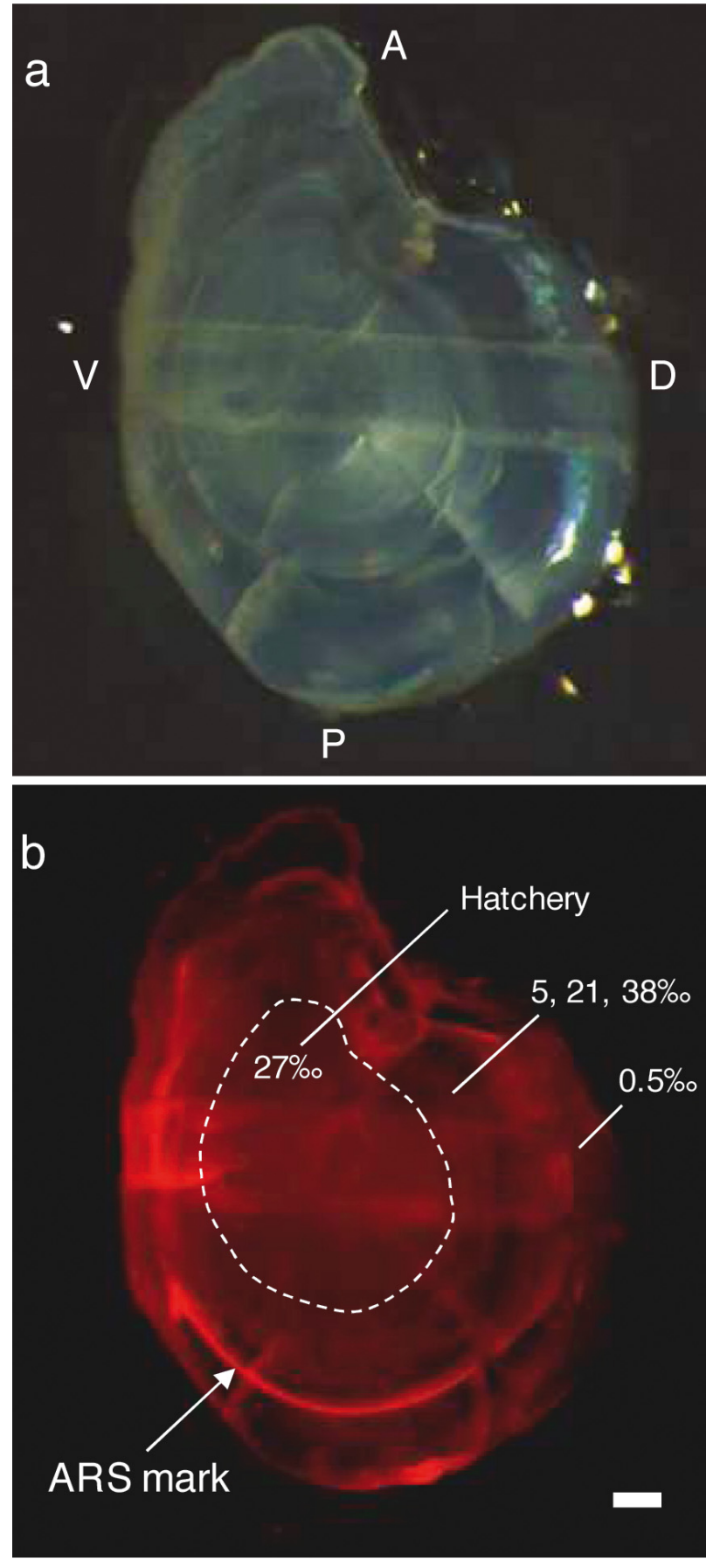

Fig. 1. Macquaria novemaculeata. A representative juvenile Australian bass sagittal otolith after marking with alizarin red $\mathrm{S}$ (ARS). (a) Image taken with a stereomicroscope under unfiltered white light showing the position of the $100 \mu \mathrm{m}$ wide laser ablation track running from the ventral to the dorsal otolith margin through the core. A: anterior; P: posterior; V: ventral; D: dorsal. (b) Image taken under a TXR filter set, showing the position of the ARS mark and the regions of the otolith accreted when fish were kept in the hatchery $(27 \%)$, when exposed to either the 5, 21 or $38 \%$ o treatments, and after transfer to the $0.5 \%$ treatment (i.e. post-ARS marking). Scale bar $=50 \mu \mathrm{m}$ 
$(\mathrm{n}=11)$ of a secondary reference standard (NIST 610) run concurrently with the otolith samples. Mean \% RSD across all NIST 610 samples was $2.4 \%$ for Sr:Ca and $2.5 \%$ for Ba:Ca. Several authors have now reported marked enrichment of particular elements at the otolith core (e.g. Brophy et al. 2004, Ruttenberg et al. 2005, Macdonald et al. 2008). Similarly, we found distinct peaks of ${ }^{55} \mathrm{Mn}$ at the primordium of the bass otoliths, which provided a marker for the core during the transect analysis and data reduction process.

Following transect analysis, each otolith was photographed using a stereomicroscope (Model MZ16 F, Leica) coupled to image analysis software (Infinity Capture 3.5.1, Lumenera, and Image Pro Express 5.0.1.26, Media Cybernetics). Photographs were taken under unfiltered white light and a TXR filter (Leica), which was used to detect the ARS marks. This allowed us to relate the position of the otolith core and ARS mark to the corresponding time-resolved elemental concentrations along the transects. Additionally, as we knew the period of time (50 d) that the fish were kept at the $0.5 \%$ salinity treatment and the distance from the ARS mark to the dorsal otolith margin, we were able to estimate the mean otolith growth rate per day post-marking for each fish and standardise plots of $\mathrm{Sr}: \mathrm{Ca}$ and $\mathrm{Ba}: \mathrm{Ca}$ values for each individual against the estimated days post-marking.

Standardising the data in this way makes the assumption that daily otolith growth for an individual fish was relatively stable during the last $50 \mathrm{~d}$ of the experiment. To test this assumption, we examined a subset of the otoliths ( $\mathrm{n}=6,2$ from each of the $0.5 \%$ tanks) to validate the formation of daily increments and estimate variability in increment widths in the last $50 \mathrm{~d}$ of otolith growth. We examined increments accreted post-ARS marking along the dorsoventral axis immediately anterior to the ablation transect using image analysis software (Infinity Capture 3.5.1, Lumenera, and Image Pro Express 5.0.1.26, Media Cybernetics). Importantly, we found little variability in increment width distances within each of the 6 otoliths over the last $50 \mathrm{~d}$ of the experiment. Mean increment width distances ranged from 1.535 to $1.902 \mu \mathrm{m}$, with low errors around all estimates (SE range $=0.018$ to $0.029 \mu \mathrm{m}$ ).

Water chemistry and salinity. Water samples were collected from each tank on 3 separate occasions during the laboratory experiments (Tanks 1 to 6: Days 2, 34 and 71; Tanks 7 to 9: Day 73, 94 and 122) to measure ambient $\mathrm{Sr}: \mathrm{Ca}$ and $\mathrm{Ba}: \mathrm{Ca}$ concentrations in each salinity treatment. Samples were collected in $250 \mathrm{ml}$ acidwashed polypropylene bottles, filtered through a $0.45 \mu \mathrm{m}$ filter, acidified with re-distilled nitric acid and then analysed with a high-resolution ICP-MS at the National Measurement Institute, Sydney, Australia. Surface water samples were also collected from the estuarine and freshwater reaches of 7 coastal rivers across Victoria, Australia (see Fig. 5), and from the marine environment immediately adjacent to the river mouths, to compare field and laboratory relationships between salinity and ambient $\mathrm{Sr}: \mathrm{Ca}$ and Ba:Ca. Samples were collected in $250 \mathrm{ml}$ acid-washed polypropylene bottles at a depth of $\sim 5 \mathrm{~cm}$ beneath the water surface. Bottles were capped immediately and kept refrigerated at $4^{\circ} \mathrm{C}$ for transport to the laboratory. Samples were processed and analysed using identical procedures to those described above. All rivers except the Tarwin River were sampled once during summer in either 2004 or 2005, with the Bunyip, Tambo and Barwon Rivers re-sampled during winter 2006. The Tarwin River was sampled twice during winter 2006. Salinity was recorded at the time of collection.

Simple mixing models were developed for each river to predict the relationship between $\mathrm{Sr}: \mathrm{Ca}, \mathrm{Ba}: \mathrm{Ca}$ and salinity and to test these predictions against the empirical data from each river. Using the measured marine water values of $\mathrm{Sr}: \mathrm{Ca}, \mathrm{Ba}: \mathrm{Ca}$ and salinity and those from the most upstream freshwater sites as end members, Sr:Ca and Ba:Ca concentrations were estimated across the range of $100 \%$ marine water to $0 \%$ marine water at $0.1 \%$ dilution increments. Mixing curves developed from these models were plotted against the empirical Sr:Ca and $\mathrm{Ba}: \mathrm{Ca}$ values from river water samples.

Data selection and statistical analysis. Changes in fish TL among salinity treatments at Day 72 of the experiment were assessed with a nested 2-way ANOVA, with the random factor tank nested within each fixed salinity treatment. Variation in TL among $0.5 \%$ tanks at the conclusion of the experiment was examined with a 1-way ANOVA. Otolith data were selected from a $3 \times 18 \times 100 \mu \mathrm{m}$ portion of each otolith accreted immediately prior to the ARS marking (or at the dorsal otolith margin for fish from Tanks 1, 3 and 5) to represent $\sim 10 \mathrm{~d}$ of otolith growth during the period that each fish was exposed to either the 5, 21 or $38 \%$ o salinity treatments. For ARS-marked fish, data from the same amount of otolith material $(3 \times 18 \times 100 \mu \mathrm{m})$ were selected at the dorsal margin of each otolith to represent the time of exposure to the $0.5 \%$ treatment.

Non-linear and linear regression were used to relate ambient salinity and measured values of $\mathrm{Sr}: \mathrm{Ca}$ and $\mathrm{Ba}: \mathrm{Ca}$ in the otoliths and the tank water. After specifying a base function, we determined values of the model parameters that minimized the residual sum of squares. Differences in $\mathrm{Sr}: \mathrm{Ca}$ and Ba:Ca in the otoliths and tank water among the 0.5, 5, 21 and 38\% salinity treatments were examined using 1-way ANOVAs or 2-way nested ANOVAs, with salinity a fixed factor and tank a random factor nested within each salinity treatment. Data were natural $\log (\mathrm{x}+1)$-transformed where 
necessary to meet parametric assumptions of normality and homogeneity of variances among groups, and Tukey's Honestly Significant Difference (HSD) tests were used to compare group means when a significant $(p<0.05)$ ANOVA result was obtained. To compare uptake rates of $\mathrm{Sr}$ and $\mathrm{Ba}$ from the water to the otolith among salinity treatments, partition coefficients $(D$; see Morse \& Bender 1990) were calculated for each fish in each tank for a given trace metal $(\mathrm{Me})$ :

$$
D_{\mathrm{Me}}=\mathrm{Me}: \mathrm{Ca}_{\text {otolith }} / \mathrm{Me}: \mathrm{Ca}_{\text {water }}
$$

and a mean value was derived for each salinity treatment. These values were then plotted against measured salinity in the tank waters and compared with a 1-way ANOVA with salinity as a fixed factor. Linear regression was used to examine relationships between the empirical river water values of $\mathrm{Sr}: \mathrm{Ca}$ and $\mathrm{Ba}: \mathrm{Ca}$, and those predicted from the mixing models. Data for the high and low salinity end-members in each river were excluded from these analyses, as these are both empirical values and form the upper and lower bounds to the models. All statistical analyses were conducted in SYSTAT version 10 (Systat Software). Means are presented $\pm \mathrm{SE}$.

\section{RESULTS}

\section{Tank conditions}

Water temperature was relatively stable across all tanks and treatments during the experimental period, and salinity levels remained constant within a given treatment (Table 1). There was no effect of salinity on fish length at Day 72 of the experiment, and no differences between tanks within the same treatment (2-way nested ANOVA, salinity: $F_{2,30}=0.216, \mathrm{p}=0.807$; tank: $F_{3,30}=0.308, \mathrm{p}=$ 0.820). However, obvious darkening of body pigmentation was evident in most individuals maintained at the lowest salinities (i.e. 0.5 and 5\%). Mean TL at the end of $72 \mathrm{~d}$ across all treatments and tanks was $17.67 \pm 0.18 \mathrm{~mm}$. There was no significant variation in TL among the $0.5 \%$ tanks at the end of the experiment (1-way ANOVA, $F_{2,17}=0.189, \mathrm{p}=$ 0.830).

\section{Water and otolith chemistry: tank experiments}

The ambient Sr:Ca concentration in the rearing tanks increased non-linearly with salinity, with the greatest rate of change occurring between 0.5 and $5 \%$ (Fig. 2a). At $0.5 \%$, the mean Sr:Ca concentration across all water samples ( $\mathrm{n}=9$ ) was $1.89 \pm 0.01 \mathrm{mmol} \mathrm{mol}^{-1}$, rising to $6.83 \pm$ $0.13 \mathrm{mmol} \mathrm{mol}^{-1}$ at $5 \%(\mathrm{n}=6)$. At salinities $>5 \%$, $\mathrm{Sr}$ : Ca variation was relatively small, with maximum values observed at $21 \%$ o $\left(8.79 \pm 0.08 \mathrm{mmol} \mathrm{mol}^{-1}, \mathrm{n}=6\right.$; Fig. 2a). There were no differences in Sr:Ca observed between tanks for all salinity treatments tested (2-way nested ANOVA, $F_{3,12}=0.498, \mathrm{p}=0.691$ ).

A negative logarithmic function best described the relationship between water $\mathrm{Ba}: \mathrm{Ca}$ and salinity in the rearing tanks (Fig. 2a). Most notable was the large decrease in $\mathrm{Ba}: \mathrm{Ca}$ concentration from the $0.5 \%$ o (512.48 \pm $\left.5.40 \mu \mathrm{mol} \mathrm{mol}{ }^{-1}, \mathrm{n}=9\right)$ to the $5 \%$ o treatment (265.07 \pm $1.08 \mu \mathrm{mol} \mathrm{mol}{ }^{-1}, \mathrm{n}=6$ ), coinciding with a marked increase in $\mathrm{Sr}: \mathrm{Ca}$. A more gradual drop in Ba:Ca was evident from 5 to $38 \%$ (Fig. 2a). The minimum Ba:Ca $\left(11.70 \pm 0.14 \mathrm{\mu mol} \mathrm{mol}^{-1}, \mathrm{n}=6\right)$ occurred at the highest salinity tested $(38 \%$ ), and again there were no differences between tanks within each salinity treatment (2-way nested ANOVA, $F_{3,12}=0.009, \mathrm{p}=0.999$ ).

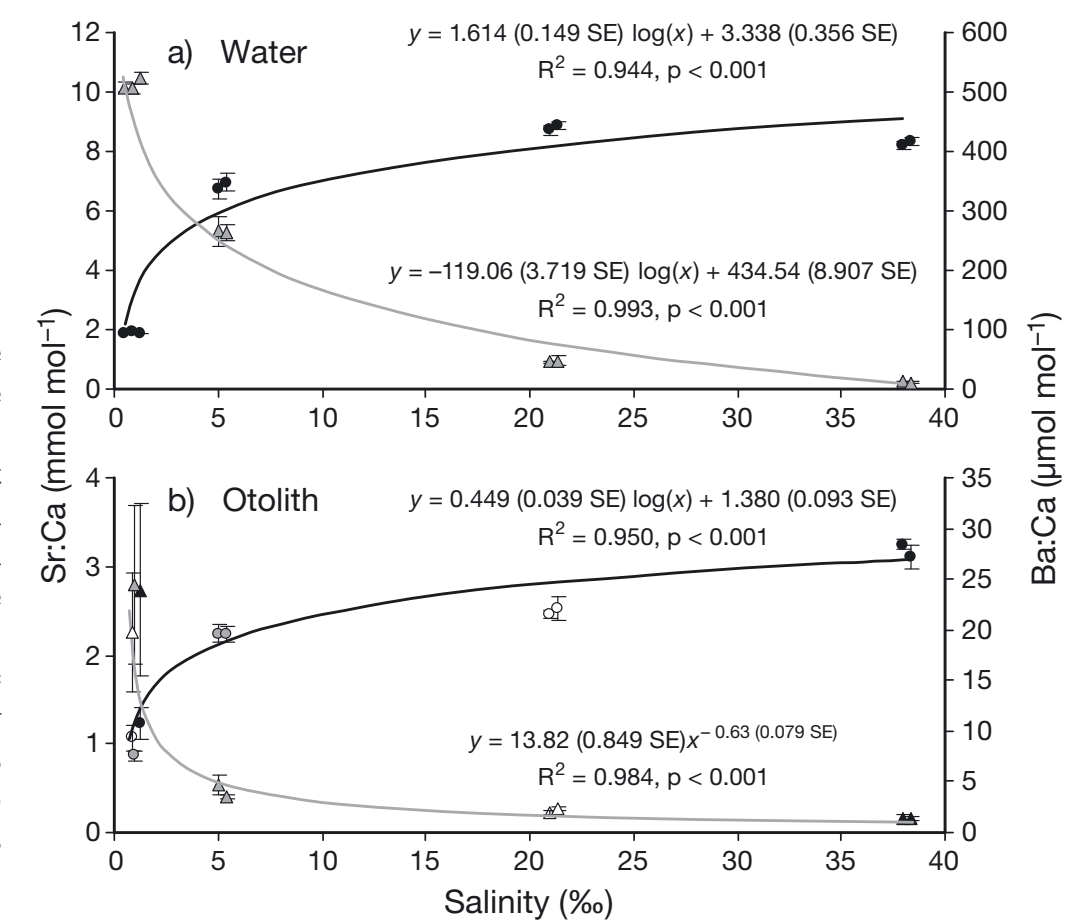

Fig. 2. Macquaria novemaculeata. (a) Relationships between water $\mathrm{Sr}: \mathrm{Ca}$ (black circles), water Ba:Ca (grey triangles) and salinity as measured in the rearing tanks. Data are mean $\pm \mathrm{SE}$ concentrations of 3 water samples collected from each tank at different times during the course of the experiment. (b) Relationships between salinity and mean \pm SE otolith $\mathrm{Sr}: \mathrm{Ca}$ (circles) and otolith Ba:Ca (triangles) measured in each tank for the 5\% (grey symbols), $21 \%$ (open symbols) and $38 \%$ (black symbols) treatments. Values for the $0.5 \%$ tanks correspond to the 5,21 or $38 \%$ treatments to which the bass were initially exposed. Curves for Sr:Ca (black lines) and Ba:Ca (grey lines) and associated equations represent the best fit to the data for each plot. Model parameters in equations are expressed \pm SE. Data points are offset slightly for clarity 
The general nature of the relationships between salinity and otolith $\mathrm{Sr}: \mathrm{Ca}$ and $\mathrm{Ba}: \mathrm{Ca}$ reflected the patterns observed for the water chemistry data. Relatively little variation in $\mathrm{Sr}: \mathrm{Ca}$ concentration was found among the original 5, 21 and 38\%o treatments, with a small but statistically significant increase from $\sim 2$ to $\sim 3 \mathrm{mmol} \mathrm{mol}^{-1}$ between 5 and $38 \%$ (2-way nested ANOVA, $F_{2,30}=51.599$, $\mathrm{p}<0.001$; Tukey's HSD, $\mathrm{p}=0.001)$. Similar to the water chemistry results, there was a marked decrease in otolith $\mathrm{Sr}: \mathrm{Ca}$ to $1.06 \pm$ $0.08 \mathrm{mmol} \mathrm{mol}^{-1}$ ( $\mathrm{n}=20$ fish pooled across tanks) when bass were transferred to the $0.5 \%$ treatments (Fig. 2b). This drop in $\mathrm{Sr}: \mathrm{Ca}$ corresponded with an abrupt elevation in otolith Ba:Ca from < 4 $\mu \mathrm{mol} \mathrm{mol}{ }^{-1}$ in the 5 to $38 \%$ o treatments to $22.62 \pm 4.10 \mathrm{\mu mol} \mathrm{mol}^{-1}$ ( $\mathrm{n}=20$ ) at $0.5 \%$. Otolith Ba:Ca was significantly higher at $5 \%$ o than at either of the 2 higher salinity treatments (2-way nested ANOVA, $F_{2,30}=16.740, \mathrm{p}<0.001$; Tukey's HSD, $21 \%$ : $p=0.001 ; 38 \%$ : $p<0.001$ ), with little difference observed between 21 and $38 \%$ (Tukey's HSD, $\mathrm{p}=0.221$ ). There was no difference in otolith $\mathrm{Sr}: \mathrm{Ca}$ or Ba:Ca observed among tanks within each of the 5, 21 or $38 \%$ treatments (Sr:Ca: 2-way nested ANOVA, $F_{3,30}=0.501, \mathrm{p}=0.685 ; \mathrm{Ba}: \mathrm{Ca}: F_{3,30}=0.975$, $\mathrm{p}=0.418$ ), and no difference in otolith $\mathrm{Sr}: \mathrm{Ca}$ (1-way ANOVA, $\left.F_{2,17}=1.53, \mathrm{p}=0.245\right)$ and Ba:Ca (1-way ANOVA, $F_{2,17}=0.119, \mathrm{p}=$ 0.888 ) among the $0.5 \%$ o tanks at the end of the $50 \mathrm{~d}$ experiment. However, individual bass within the same tank sometimes showed substantial variation in the final values of otolith $\mathrm{Sr}: \mathrm{Ca}$ and, in particular, Ba:Ca after 50 d (see Figs. 2b, 3b \& 4).

A strong positive linear relationship was found between otolith $\mathrm{Sr}: \mathrm{Ca}$ and water Sr:Ca (Fig. 3a), and a positive exponential relationship was observed between $\mathrm{Ba}: \mathrm{Ca}$ in otoliths and water (Fig. 3b). Examination of the partition coefficients for each element illustrates that the uptake of both $\mathrm{Sr}$ and $\mathrm{Ba}$ into the juvenile bass otoliths changed across the salinity gradient, with uptake maximised at the lowest and highest salinities examined (Fig. 3c). Uptake of $\mathrm{Sr}$ was greatest at $0.5 \%$ o $($ mean $=0.56 \pm 0.044)$ and lower at 5 and $21 \%$ o $\left(D_{\mathrm{Sr}}=\sim 0.30\right)$, with an increase to $\sim 0.38$ at $38 \%$. Ba uptake was highest at $38 \%$ o $\left(D_{\mathrm{Ba}}=0.119 \pm\right.$ 0.019 ) and varied substantially among individuals within the same tank, as demonstrated by the large error values (Fig. 3c). The rate of uptake declined with
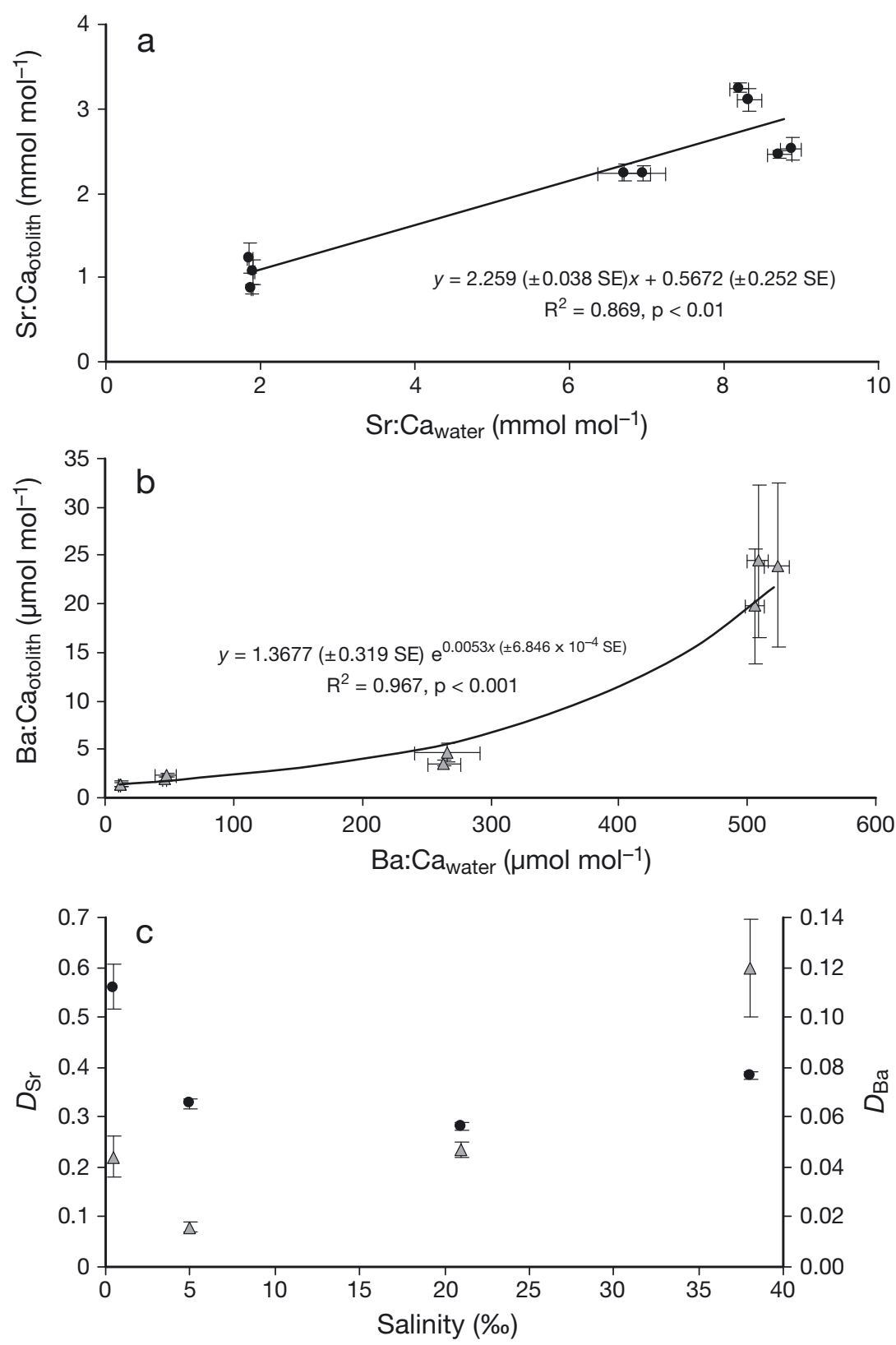

Fig. 3. Macquaria novemaculeata. Relationships between water and otolith (a) $\mathrm{Sr}$ :Ca and (b) Ba:Ca concentrations in each rearing tank. Data are mean \pm SE concentrations measured for all water samples and all fish in each tank. Linear regression results shown in (a) and exponential curve in (b) represent the best fit to the data. Model parameters in equations are expressed $\pm \mathrm{SE}$. (c) Variation in partition coefficients $D_{\mathrm{Sr}}$ (black circles) and $D_{\mathrm{Ba}}$ (grey triangles) among the $0.5,5,21$ and $38 \%$ treatments. Data are means $\pm \mathrm{SE}$ for all fish in each salinity treatment

salinity to $0.047 \pm 0.003$ at $21 \%$ and $0.016 \pm 0.002$ at $5 \%$. Like $D_{\mathrm{Sr}}$, there was an increase in $D_{\mathrm{Ba}}$ at $0.5 \%$ to $0.044 \pm 0.008$ with substantial individual variation in uptake rates after transfer to the $0.5 \%$ o treatment.

Examination of the otolith transect data from bass transferred from the 5, 21 and $38 \%$ o treatments to the $0.5 \%$ treatment revealed complex and variable re- 
sponses in both elemental ratios, but for Ba:Ca in particular (Fig. 4). For all individuals tested, a distinct time lag was apparent before the concentration of each elemental ratio reached a stable level (Fig. 4). With regard to $\mathrm{Sr}: \mathrm{Ca}$, although the final concentrations at Day 50
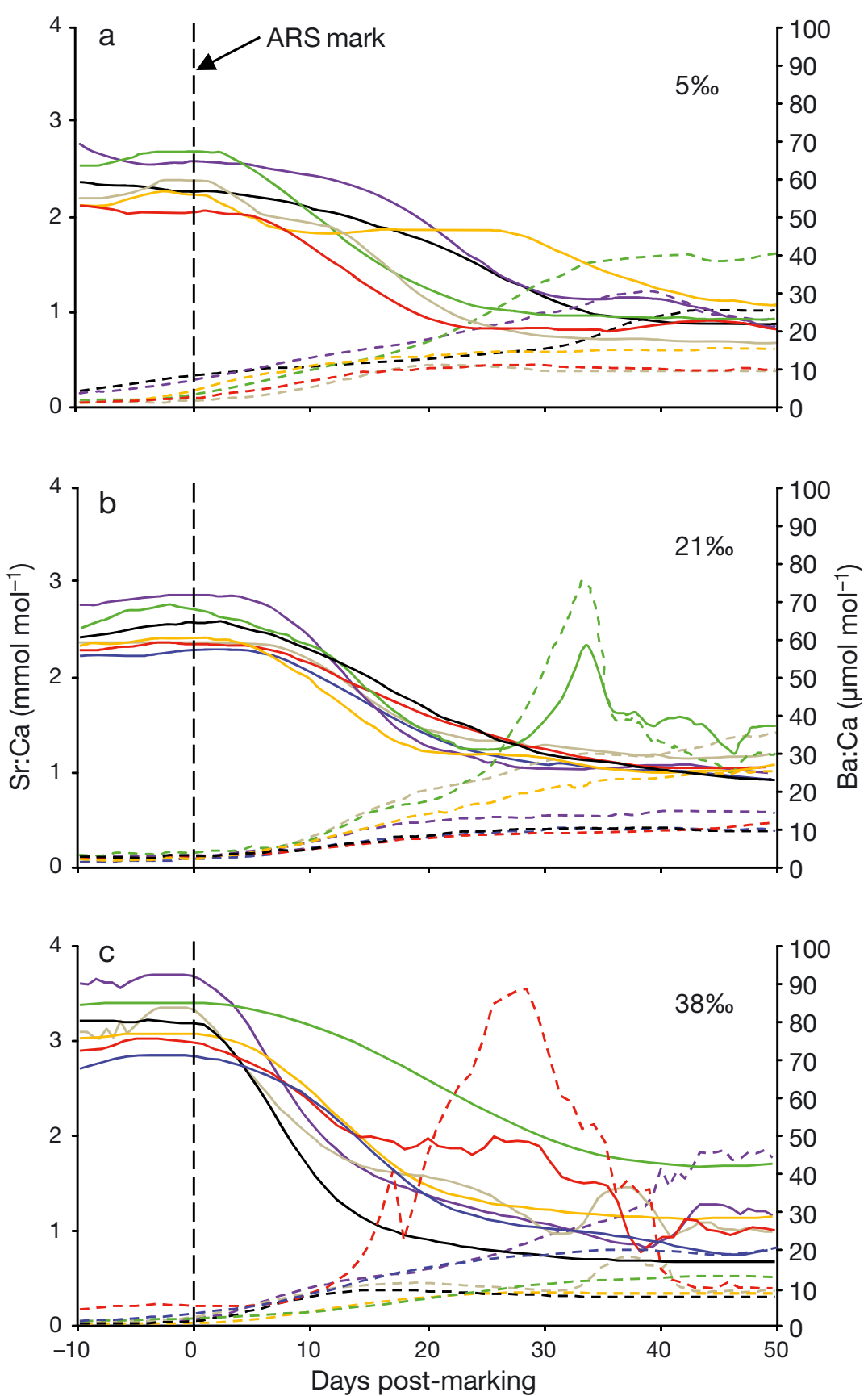

Fig. 4. Macquaria novemaculeata. Plots displaying changes in $\mathrm{Sr}$ :Ca (solid lines) and Ba:Ca (dashed lines) over a $50 \mathrm{~d}$ period following alizarin red $\mathrm{S}$ (ARS) marking and transfer from either (a) $5 \%$, (b) $21 \%$ or (c) $38 \%$ treatments to the $0.5 \%$ treatment. Within each salinity treatment, all fish were exposed to identical experimental conditions within the same tank. Concomitant variation in $\mathrm{Sr}: \mathrm{Ca}$ and Ba:Ca over time is shown for each fish in each tank by reference to solid and broken lines of the same colour. Data are presented from $10 \mathrm{~d}$ prior to ARS marking for comparison were relatively consistent among the 3 tanks, there was some within-tank variability, most notably when fish were transferred from 38 to $0.5 \%$ o (Fig. 4c). Additionally, Sr:Ca did not reach a stable level in the otolith for at least $20 \mathrm{~d}$ after bass were transferred to the $0.5 \%$ treatment, with some individuals taking $>30 \mathrm{~d}$ and one $40 \mathrm{~d}$ (see Fig. 4a). A similar lag effect was observed with the uptake of $\mathrm{Ba}: \mathrm{Ca}$, although again some individuals responded more quickly than others, both within and among tanks (e.g. Fig. 4a,b). It typically took between $\sim 10$ and $\sim 30 \mathrm{~d}$ after transfer to the $0.5 \%$ o treatment for a stable $\mathrm{Ba}$ :Ca value to be reached. Some otolith transects were characterised by large $\mathrm{Ba}: \mathrm{Ca}$ peaks reaching $\sim 90 \mu \mathrm{mol} \mathrm{mol}^{-1}$ before concentrations decreased to a more stable value (e.g. Fig. 4b,c), whilst transects of other bass exposed to identical experimental conditions within the same tank displayed no major peaks and a more gradual increase in Ba:Ca before reaching a stable value (see Fig. 4c). Importantly, the equilibrium value where $\mathrm{Ba}: \mathrm{Ca}$ concentration became stable varied widely among individuals in the same tank.

\section{River water chemistry}

The mixing curves derived from our models provided a good fit to the empirical data collected in each of the 7 rivers (Figs. 5 \& 6). The relationships between salinity and water $\mathrm{Sr}: \mathrm{Ca}$ and $\mathrm{Ba}: \mathrm{Ca}$ appear to follow a similar non-linear pattern to those observed in the laboratory experiments, with relatively small variation in Sr:Ca and Ba:Ca above a threshold salinity value of $\sim 5 \%$. The general nature of these relationships was consistent for all water samples collected regardless of the collection season (see Fig. 5); however, Sr:Ca values were substantially lower during winter in the 3 rivers where both summer and winter collections were made (Bunyip, Tambo and Barwon; Fig. 5).

\section{DISCUSSION}

The present study examined the response of $\mathrm{Sr}: \mathrm{Ca}$ and $\mathrm{Ba}: \mathrm{Ca}$ in water and otoliths across the full range of salinities commonly experienced by euryhaline 

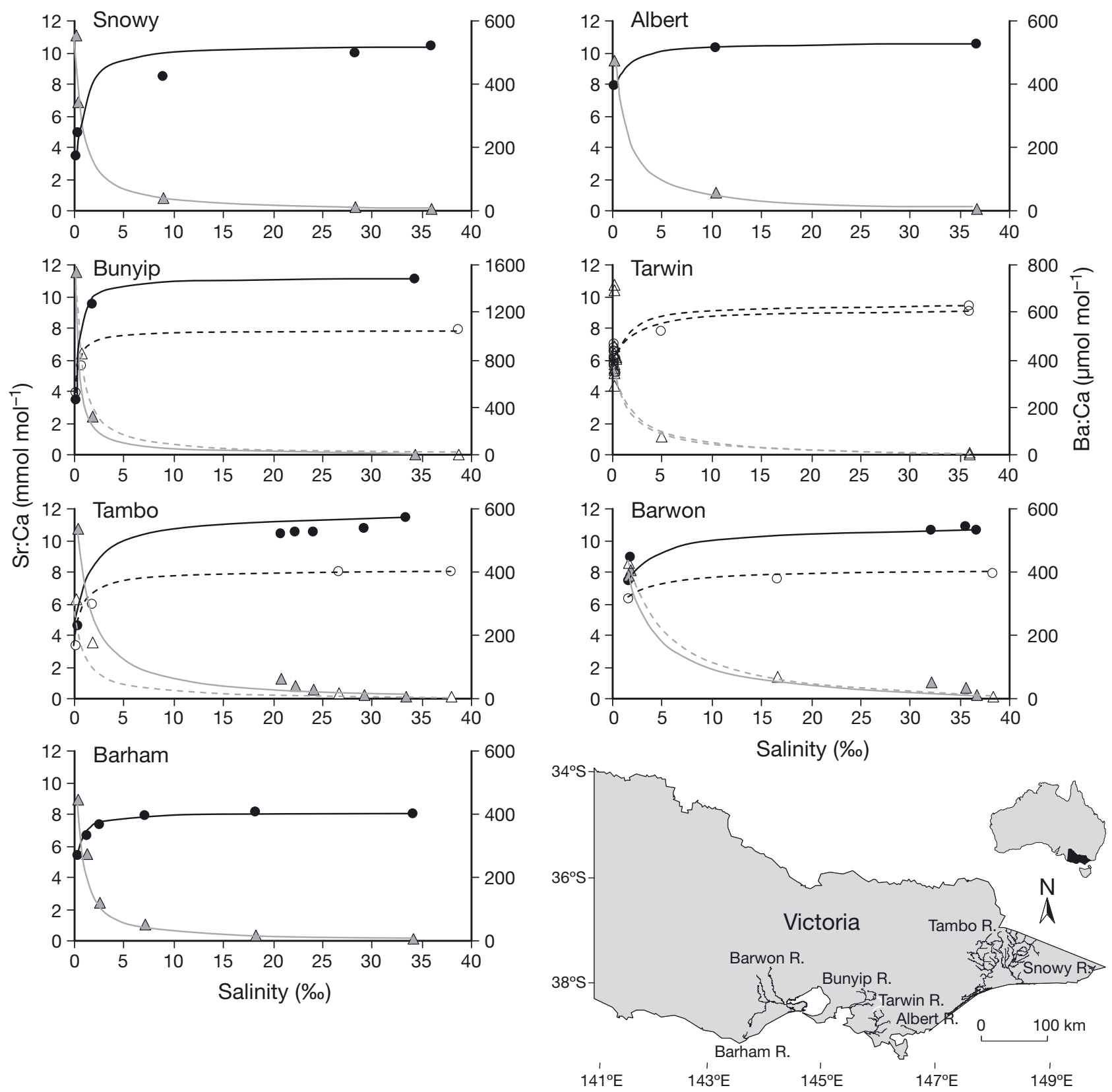

Fig. 5. Relationships between surface water Sr:Ca (black lines), Ba:Ca (grey lines) and salinity for 7 coastal rivers in southern Victoria, Australia (see map for locations). For all rivers, empirical values for Sr:Ca and Ba:Ca measured in water samples are denoted by circles and triangles, respectively. Summer water samples are represented by filled symbols, and winter water samples from the Bunyip, Tarwin, Tambo and Barwon Rivers are represented by open symbols. Solid lines represent mixing curves derived from dilution models for summer water samples, with dashed lines representing winter samples. Models used empirically derived marine and full freshwater values as salinity end-members to predict the gradient of Sr:Ca and Ba:Ca in each river at $0.1 \%$ salinity dilution increments

fishes. In the analyses of otolith and water chemistry from our laboratory experiments, in addition to the water samples collected from 7 coastal rivers, we found strong, consistent non-linear relationships between salinity, $\mathrm{Sr}: \mathrm{Ca}$ and $\mathrm{Ba} \mathrm{Ca}$, with the greatest rate of change in elemental concentrations occurring at salinities $<5 \%$. The nature of these relationships appears to depend greatly on the inclusion of the lowest salinity treatment at $0.5 \%$. Positive logarithmic responses in water and otolith $\mathrm{Sr}: \mathrm{Ca}$ with increasing salinity have been reported previously, but only in studies that have incorporated low (i.e. $<2 \%$ ) salinity levels (e.g. Kraus \& Secor 2004, Zimmerman 2005, Kerr et al. 2007). In higher salinity environments, laboratory and field- 

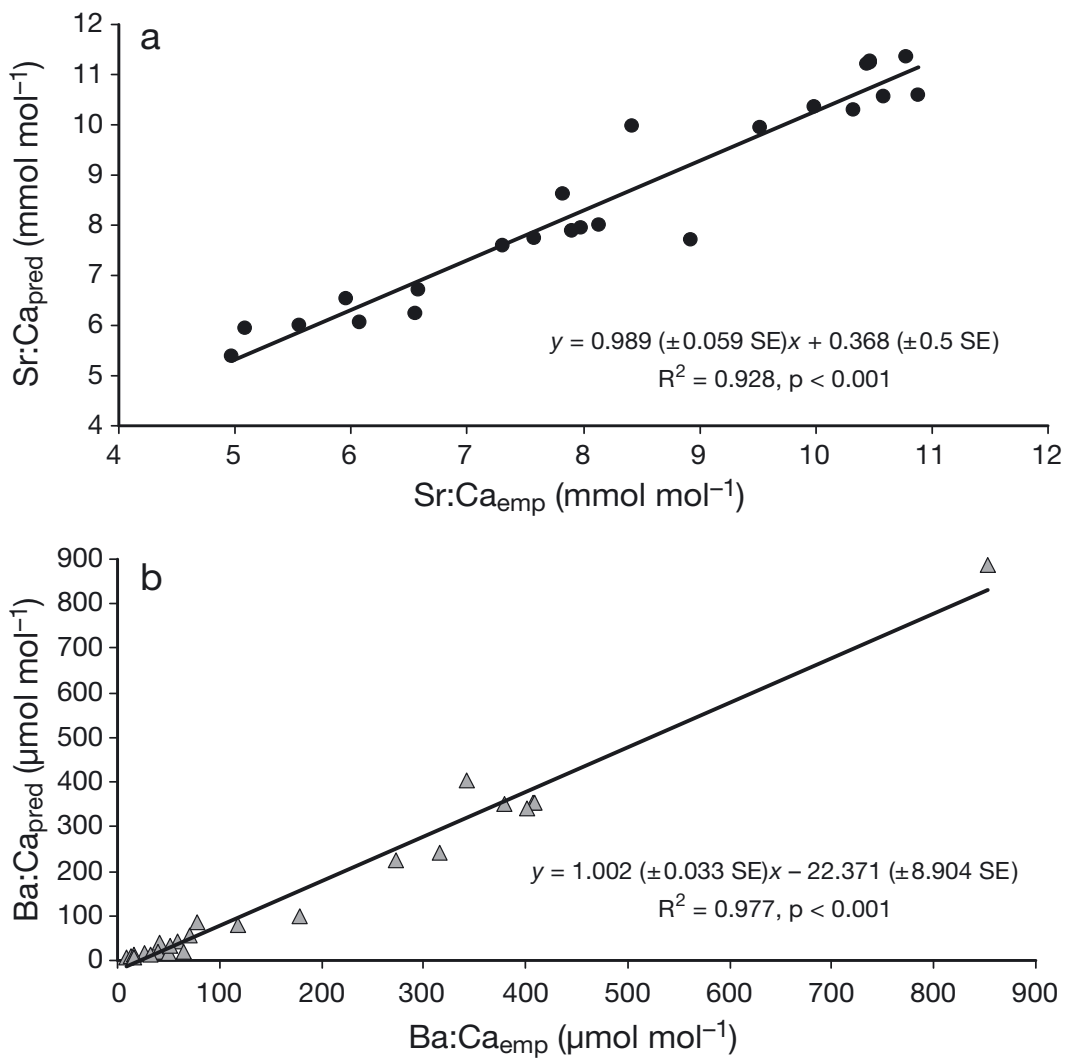

Fig. 6. Correlation between empirical values for (a) $\mathrm{Sr}: \mathrm{Ca}\left(\mathrm{Sr}: \mathrm{Ca}_{\mathrm{emp}}\right)$ and (b) $\mathrm{Ba}: \mathrm{Ca}\left(\mathrm{Ba}: \mathrm{Ca}_{\mathrm{emp}}\right)$ measured from the river water samples and values predicted at a given salinity from the dilution models $\left(\mathrm{Sr}: \mathrm{Ca}_{\text {pred }}\right.$ and $\mathrm{Ba}: \mathrm{Ca}$ pred $)$. Simple linear regression results are presented for each plot with model parameters expressed $\pm \mathrm{SE}$

based studies have described linear relationships (e.g. Martin \& Wuenschel 2006) or no relationship (Elsdon \& Gillanders 2005a, Dorval et al. 2007) between otolith and/or water Sr:Ca and salinity. When data for $0.5 \%$ were removed from our analyses, the association between otolith $\mathrm{Sr}: \mathrm{Ca}$ and salinity adhered to a weakly positive linear relationship (linear regression, $\mathrm{Sr}: \mathrm{Ca}_{\text {otolith }}=0.028$ (salinity) $+2.206, \mathrm{R}^{2}=0.927, \mathrm{p}<$ 0.01). Variation in both water and otolith Sr:Ca was minimal between 5 and $38 \%$, suggesting that movements of bass between estuarine and marine environments may not be resolvable using otolith Sr:Ca alone.

High Ba:Ca values such as those measured in our aquarium and river water samples (i.e. $>500 \mu \mathrm{mol} \mathrm{mol}^{-1}$ ) have generally only been reported in entirely freshwater systems exhibiting very low salinities (e.g. Wells et al. 2003, Gibson-Reinemer et al. 2009). However, in the few studies that have examined variation in water Ba:Ca across a large salinity gradient (e.g. Elsdon \& Gillanders 2005a, Crook et al. 2006, 2008, Martin \& Wuenschel 2006), a negative non-linear relationship is apparent. The negative correlation between otolith $\mathrm{Ba}: \mathrm{Ca}$ and salinity has been well documented in field studies in estuaries, but the nature of the relationship has been shown to vary from linear (Elsdon \& Gillanders 2005b) to exponential (Dorval et al. 2007) depending on the species examined. By contrast, in their work on elemental uptake in gray snapper Lutjanus griseus, Martin \& Wuenschel (2006) observed no discernable relationship between otolith $\mathrm{Ba}: \mathrm{Ca}$ and salinity across salinities of 5 to $45 \%$, despite reporting a clear negative exponential trend in water Ba:Ca with increasing salinity. Our data suggest a decreasing non-linear relationship for both otolith Ba:Ca in bass and water Ba:Ca as salinity increases, with otolith Ba:Ca responding more gradually than $\mathrm{Sr}: \mathrm{Ca}$ to equivalent salinity changes.

Like several previous laboratory studies (e.g. Bath et al. 2000, Elsdon \& Gillanders 2003, Martin et al. 2004), we observed a strong positive linear relationship between otolith Sr:Ca and water Sr:Ca in our experimental tanks. The relationship between partition coefficients for $\mathrm{Sr}\left(D_{\mathrm{Sr}}\right)$ and salinity was not linear, with the maximum $D_{\mathrm{Sr}}$ observed at our lowest salinity treatment $(0.5 \%$ ) and only minor differences between 5 and $38 \%$. A similar pattern was reported by Zimmerman (2005), who found that $D_{\mathrm{Sr}}$ in 5 species of salmonids was highest at the lowest salinity tested $(0.1 \%)$, declined to a minimum value at the next highest salinity $(6.3 \%)$ and gradually increased thereafter (see also Elsdon \& Gillanders 2005a). Several other studies that have examined uptake rates of $\mathrm{Sr}$ and $\mathrm{Ba}$ have related $D$ to ambient water concentrations, observing, in general, greater uptake of $\mathrm{Sr}: \mathrm{Ca}$ and $\mathrm{Ba}: \mathrm{Ca}$ at lower ambient concentrations (e.g. Bath et al. 2000, de Vries et al. 2005, Elsdon \& Gillanders 2005a). Our data for Sr:Ca showed a similar pattern, with $D_{\text {Sr }}$ reaching a maximum at the lowest ambient concentrations measured $\left(\sim 2 \mathrm{mmol} \mathrm{mol}^{-1}\right)$, dropping substantially at $\sim 7 \mathrm{mmol}$ $\mathrm{mol}^{-1}$ (as salinity increased from 0.5 to $5 \%$ ) then remaining relatively stable at higher ambient concentrations. These results may reflect differential pathways of Sr uptake into the blood plasma between freshwater (branchial uptake) and marine (intestinal uptake) environments (Olsson et al. 1998), with subsequent effects on endolymph and otolith concentrations and/or regulation of $\mathrm{Sr}^{2+}$ and $\mathrm{Ca}^{2+}$ activity within the endolymph (Payan et al. 2002). Data on ionic concentrations and activity levels in the endolymph would be required to directly test these hypotheses.

The positive relationship between otolith and water $\mathrm{Ba}$ :Ca was best described by an exponential equation, which differs somewhat from the logarithmic (Elsdon \& Gillanders 2005b) or linear (Bath et al. 2000, Wells et 
al. 2003) relationships reported previously. Moreover, $D_{\mathrm{Ba}}$ values (0.016 to 0.119$)$ were relatively low compared with some previous studies on other estuarine species (e.g. Elsdon \& Gillanders 2002, Martin \& Wuenschel 2006), indicating a large degree of discrimination between $\mathrm{Ba}$ : Ca in water and otoliths of juvenile bass. Uptake of Ba:Ca followed the expected nonlinear decreasing trend, with increased ambient $\mathrm{Ba}: \mathrm{Ca}$ and decreasing salinity as found in other studies (e.g. Bath et al. 2000, Elsdon \& Gillanders 2005a, but see Martin \& Wuenschel 2006), with evidence of a thresh-

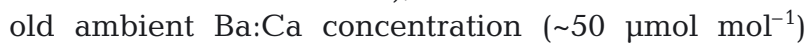
above which variation in $D_{\mathrm{Ba}}$ is quite small (see also Elsdon \& Gillanders 2005a, Miller 2009). However, at the lowest salinity treatment, which coincides with maximum ambient Ba:Ca values ( 500 $\left.\mu \mathrm{mol} \mathrm{mol}^{-1}\right)$ and

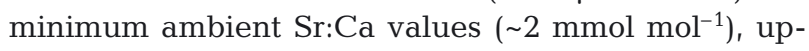
take appeared to be somewhat enhanced. This may be due to the greater availability of free Ba to fish in freshwater versus saltwater (Turner et al. 1981), although marked variation in $D_{\mathrm{Ba}}$ both within and among experimental tanks at $0.5 \%$ suggests that individual bass may respond quite differently when exposed to such high ambient $\mathrm{Ba}$ :Ca concentrations. Our observations of maximum $D_{\mathrm{Ba}}$ values in the seawater treatment could be a result of facilitation of Ba uptake at high water Sr:Ca concentrations, as found by de Vries et al. (2005) for black bream Acanthopagrus butcheri. However, as water Sr:Ca did not change dramatically over salinities of $5 \%$, whilst $D_{\mathrm{Ba}}$ did, other factors (e.g. increased availability of $\mathrm{Ba}^{2+}$ binding sites, variable uptake pathways) are likely to be involved.

Indeed, the uptake of $\mathrm{Sr}$ and Ba into otoliths may not only reflect the chemistry and salinity of the water in which the fish has resided at particular life stages, but can also be influenced by water temperature (Bath et al. 2000, Martin et al. 2004), growth rates (Sadovy \& Severin 1994, Martin \& Thorrold 2005), ontogeny (de Pontual et al. 2003), physiology (Kalish 1989, 1991), diet (Farrell \& Campana 1996, Kennedy et al. 2000) or processes relating to otolith crystallisation (Melancon et al. 2008). Whilst direct examination of these factors was beyond the scope of the present study, it is important to note that with strong evidence for temperature dependence of otolith Sr (Martin et al. 2004, but see Kalish 1991) and Ba (Elsdon \& Gillanders 2002, but see Bath et al. 2000) in some species, and the fact that water temperature may vary widely across days and seasons at the same location in estuaries (Elsdon \& Gillanders 2006), our data potentially underestimate the complexity in the otolith chemistry-salinity relationships that may exist in natural systems.

In light of this, one of the most interesting findings of the present study was the highly unpredictable response in otolith Ba:Ca when bass were transferred from higher salinities to the lowest salinity treatment $(0.5 \%$ o). Despite the controlled chemical environment, stable temperature regime and standardised diet, distinct individual variability was observed in relation to both the magnitude and timing of Ba:Ca uptake. Most notably, some fish exhibited very large Ba:Ca peaks immediately following transfer into the low salinity treatment before concentrations returned to lower and more stable values towards the end of the experiment. These results may help explain the findings of several field-based studies that have reported large peaks in Ba:Ca associated with movements from the sea into lower salinity environments (e.g. Crook et al. 2006, Hale \& Swearer 2008). Otolith Sr:Ca responded more predictably in relation to the final equilibrium values reached after transfer to $0.5 \%$. However, some variability in these values within tanks was still apparent, and the timing of the drop in Sr:Ca also differed substantially among individuals in the same tank. The reasons for such individual variability are unclear. Previous work on $\mathrm{Sr}$ incorporation in marine Australian salmon Arripis trutta, blue grenadier Macruronus novaezelandiae and bearded rock cod Pseudophycis barbatus points to physiological factors related to changes in blood plasma and endolymph chemistry, otolith growth rates and reproductive investment as the major determinants of $D_{\mathrm{Sr}}$ in these species (Kalish 1989, 1991). Furthermore, changes in an individual's ability to osmoregulate as they grow or acclimate to different salinity environments (e.g. Jensen et al. 1998, Herrera et al. 2009) may also affect transfer of ions such as $\mathrm{Sr}^{2+}$ across gills and other epithelial membranes into the blood, which in turn may influence endolymph and otolith Sr composition (Kalish 1991). It is possible that juvenile bass within the same tank had different osmoregulatory and physiological responses to the transfer to the lowest salinity treatment in our experiment, which may explain some of the variation we observed. Although recent work has suggested that $\mathrm{Sr}$ and $\mathrm{Ba}$ incorporation is driven primarily by environmental factors of water chemistry, salinity and temperature in other species (e.g. Elsdon \& Gillanders 2004, Walther \& Thorrold 2006), further research into the processes controlling ion transport from water to the otolith (e.g. Payan et al. 2002, Melancon et al. 2009) may help elucidate the roles of ontogeny and physiology in driving elemental uptake across salinity gradients.

Regardless of the mechanisms at play, our findings of substantial and variable time lags in the uptake of $\mathrm{Sr}: \mathrm{Ca}$ and $\mathrm{Ba}: \mathrm{Ca}$ and large individual differences in equilibrium values at the conclusion of the experiment have obvious potential implications for reconstructing the salinity histories of bass and other euryhaline species using these elements. For fish that undertake 
rapid movements across salinity gradients within estuaries, the presence of time lags means that the residence time in a given salinity environment may be too short for a chemical signal representing ambient salinity to be accurately reflected in the otolith. Consequently, particular $\mathrm{Sr}: \mathrm{Ca}$ or $\mathrm{Ba}: \mathrm{Ca}$ values could either represent equilibrium with the ambient water or transitional values at some unknown stage within a time lag period. Distinguishing the difference between these possibilities is very difficult without subsidiary information (e.g. detailed water chemistry and fish movement data). Furthermore, our data suggest that even if fish remain in a stable salinity environment for long enough to reach equilibrium, individual variation in the magnitude of uptake may hinder accurate reconstructions of environmental histories across small salinity gradients, particularly at higher salinities (>5\%) where water $\mathrm{Sr}: \mathrm{Ca}$ and $\mathrm{Ba}: \mathrm{Ca}$ are relatively invariant. Despite these issues, large changes in otolith $\mathrm{Sr}: \mathrm{Ca}$ and Ba:Ca observed for fish transferred between $0.5 \%$ and the higher salinity treatments suggest that movements at coarser scales, such as between freshwater and marine environments or where salinity and temperature gradients are stable for extended periods, may be resolvable using these 2 elements either alone or in combination.

To illustrate the difficulties often faced when interpreting otolith chemistry data from wild-caught fish, we have included $\mathrm{Sr}: \mathrm{Ca}$ and $\mathrm{Ba}: \mathrm{Ca}$ transect data from the otoliths of 3 adult Australian bass captured in the Albert River, Victoria, Australia (Fig. 7). The complex nature of the data is evident, with the 3 fish showing variable patterns in $\mathrm{Sr}: \mathrm{Ca}$, marked cycling in $\mathrm{Ba}: \mathrm{Ca}$, particularly in the outer otolith growth regions, and no consistent positive or negative relationships between $\mathrm{Sr}: \mathrm{Ca}$ and Ba:Ca across the transects. So how should we interpret these patterns? Do the inverse relationships between $\mathrm{Sr}: \mathrm{Ca}$ and $\mathrm{Ba}: \mathrm{Ca}$ near to the otolith core reflect estuarine and/or marine residence as juveniles? Does the cycling of Ba:Ca (Fig. 7b,c) represent movements between freshwater and the estuary as adults? What does it mean when $\mathrm{Sr}: \mathrm{Ca}$ and $\mathrm{Ba}: \mathrm{Ca}$ appear positively correlated? Can we define when an actual movement across a salinity gradient has occurred, compared with a change in salinity at the same location? Without intimate knowledge of the salinity, temperature and ambient elemental concentration gradients in the Albert River over the lifetimes of these bass, answering such questions with any confidence is not possible. Furthermore, as elemental uptake rates may shift with ontogeny (de Pontual et al. 2003), the relationships derived between salinity and ambient and otolith elemental concentrations for juvenile bass cannot necessarily be extrapolated to older fish without first assessing any age-related effects.
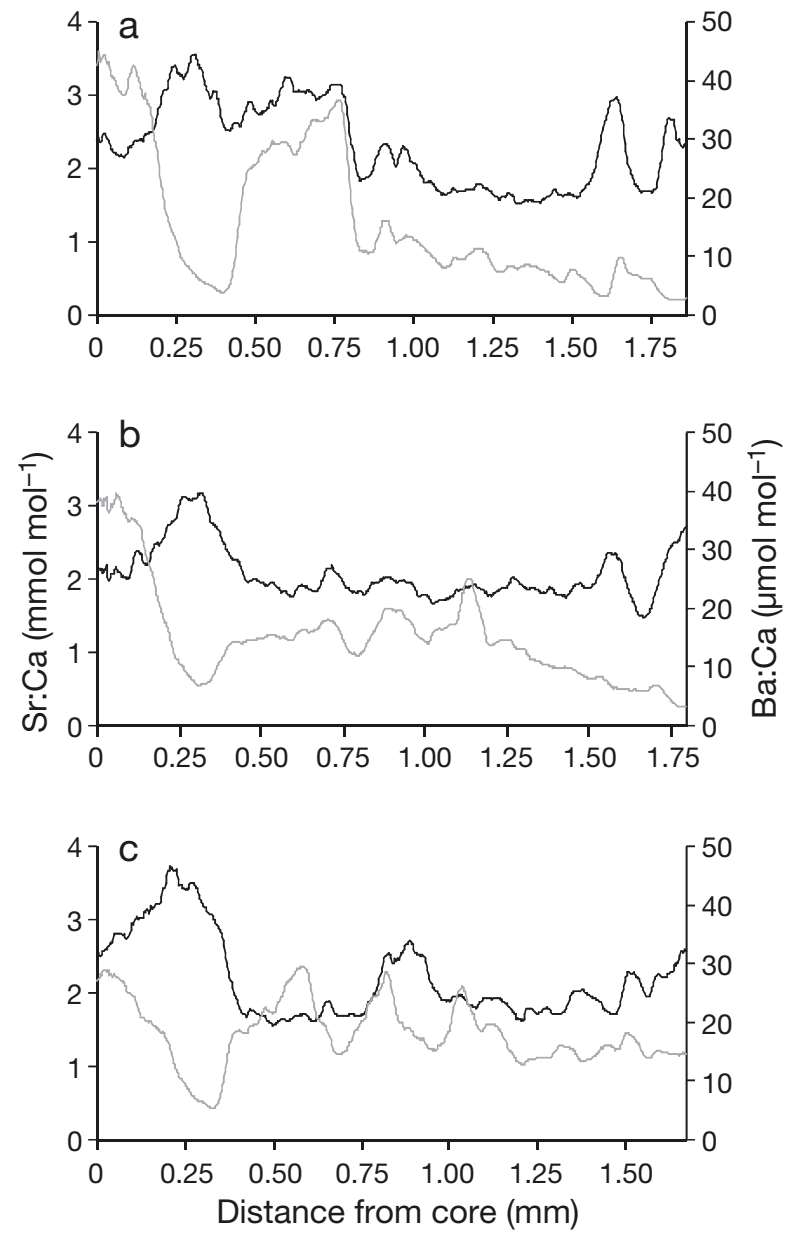

Fig. 7. Macquaria novemaculeata. Plots of otolith Sr:Ca (black lines) and Ba:Ca (grey lines) measured across the lifetimes of 3 adult bass of fork length (a) $357 \mathrm{~mm}$, (b) $318 \mathrm{~mm}$ and (c) $305 \mathrm{~mm}$, collected in December 1995 from the Albert River, Victoria, Australia. Sagittal otoliths were sectioned transversely through the core and $30 \mu \mathrm{m}$ wide ablation transects run from the core to the dorsal lip of the medial groove. The analytical methods and operating parameters used were identical to those described by Crook et al. (2006)

The complex and variable nature of both the movements of euryhaline fishes and the environments they inhabit continues to pose major challenges for accurately retracing environmental histories in these systems using otolith chemistry methods. Whilst otolith $\mathrm{Sr}: \mathrm{Ca}$ and $\mathrm{Ba}: \mathrm{Ca}$ have clearly proved useful as indicators of movement by fish across coarse salinity gradients (e.g. Elsdon \& Gillanders 2005b, McCulloch et al. 2005, Crook et al. 2006), the complexity of the data as observed in the present study suggests that the addition of alternative chemical markers to augment the measurement of trace element concentrations may aid interpretation at finer scales. Recent advances in the analytical capacities of sampling equipment have allowed researchers to explore the 
use of other elements and isotopes (e.g. $\mathrm{Sr}^{87}: \mathrm{Sr}^{86}$, $\delta^{18} \mathrm{O}, \delta^{13} \mathrm{C}, \delta \mathrm{D}$ and $\delta \mathrm{S}$ ) to track dispersal, migratory and thermal histories at fine scales (Kennedy et al. 1997, Weber et al. 2002, Milton \& Chenery 2005, Whitledge et al. 2006, Kerr et al. 2007, Weidel et al. 2007). By examining the mechanisms controlling incorporation of these markers into otoliths and considering the potential limitations of each with regard to the species of interest, it may be possible to trace the transition between freshwater, estuarine and marine environments for euryhaline species with greater confidence and accuracy.

Acknowledgements. Several colleagues at the Arthur Rylah Institute for Environmental Research assisted with this work. In particular, we thank D. Dawson for help with data reduction and processing, and D. O'Mahony and K. Pomorin for feeding and monitoring fish during the laboratory experiments. Thanks also to S. Eggins, M. Shelley and G. Yaxley from the Research School of Earth Sciences at the Australian National University for valuable discussions on the analytical methods and for running some of the otolith samples. D. Erler at the RMIT Marine Research facility provided the juvenile bass. J. Hindell and 3 anonymous reviewers improved earlier drafts of the manuscript. This research was supported by funding from the Victorian Department of Sustainability and Environment and the work was conducted under ethics permit ARI AEC 06/31.

\section{LITERATURE CITED}

Bath GE, Thorrold SR, Jones CM, Campana SE, McLaren JW, Lam JWH (2000) Strontium and barium uptake in aragonitic otoliths of marine fish. Geochim Cosmochim Acta 64:1705-1714

Battaglene SC, Selosse PM (1996) Hormone-induced ovulation and spawning of captive and wild broodfish of the catadromous Australian bass, Macquaria novemaculeata (Steindachner), (Percichthyidae). Aquac Res 27:191-204

Brenner M, Krumme U (2007) Tidal migration and patterns in feeding of the four-eyed fish Anableps anableps L. in a north Brazilian mangrove. J Fish Biol 70:406-427

Brophy D, Jeffries TE, Danilowicz BS (2004) Elevated manganese concentrations at the cores of clupeid otoliths: possible environmental, physiological, or structural origins. Mar Biol 144:779-786

Campana SE (1999) Chemistry and composition of fish otoliths: pathways, mechanisms and applications. Mar Ecol Prog Ser 188:263-297

> Campana SE, Neilson JD (1985) Microstructure of fish otoliths. Can J Fish Aquat Sci 42:1014-1032

> Crook DA, Macdonald JI, O'Connor JP, Barry B (2006) Use of otolith chemistry to examine patterns of diadromy in the threatened Australian grayling. J Fish Biol 69:1330-1344

Crook DA, O'Mahony DJ, Gillanders BM, Munro AR, Sanger AC (2007) Production of external fluorescent marks on golden perch fingerlings through osmotic induction marking with alizarin red S. N Am J Fish Manag 27:670-675

$>$ Crook DA, Macdonald JI, Raadik TA (2008) Evidence of diadromous movements in a coastal population of southern smelts (Retropinninae: Retropinna) from Victoria, Australia. Mar Freshw Res 59:638-646 de Pontual H, Largardère F, Amara R, Bohn M, Ogor A (2003) Influence of ontogenetic and environmental changes in the otolith microchemistry of juvenile sole (Solea solea). J Sea Res 50:199-210

de Vries MC, Gillanders BM, Elsdon TS (2005) Facilitation of barium uptake into fish otoliths: influence of strontium concentration and salinity. Geochim Cosmochim Acta 69: 4061-4072

Donohoe CJ, Adams PB, Royer CF (2008) Influence of water chemistry and migratory distance on ability to distinguish progeny of sympatric resident and anadromous rainbow trout (Oncorhynchus mykiss). Can J Fish Aquat Sci 65: 1060-1075

Dorval E, Jones CM (2005) Chemistry of surface waters: distinguishing fine-scale differences in sea grass habitats of Chesapeake Bay. Limnol Oceanogr 50:1073-1083

Dorval E, Jones CM, Hannigan R, Van Montfrans J (2007) Relating otolith chemistry to surface water chemistry in a coastal plain estuary. Can J Fish Aquat Sci 64:411-424

- Elsdon TS, Gillanders BM (2002) Interactive effects of temperature and salinity on otolith chemistry: challenges for determining environmental histories of fish. Can J Fish Aquat Sci 59:1796-1808

Elsdon TS, Gillanders BM (2003) Relationship between water and otolith elemental concentrations in juvenile black bream Acanthopagrus butcheri. Mar Ecol Prog Ser 260: 263-272

Elsdon TS, Gillanders BM (2004) Fish otolith chemistry influenced by exposure to multiple environmental variables. J Exp Mar Biol Ecol 313:269-284

Elsdon TS, Gillanders BM (2005a) Consistency of patterns between laboratory experiments and field collected fish in otolith chemistry: an example and applications for salinity reconstructions. Mar Freshw Res 56:609-617

> Elsdon TS, Gillanders BM (2005b) Alternative life-history patterns of estuarine fish: barium in otoliths elucidates freshwater residency. Can J Fish Aquat Sci 62:1143-1152

Elsdon TS, Gillanders BM (2005c) Strontium incorporation into calcified structures: separating the effects of ambient water concentration and exposure time. Mar Ecol Prog Ser 285:233-243

Elsdon TS, Gillanders BM (2006) Temporal variability in strontium, calcium, barium, and manganese in estuaries: implications for reconstructing environmental histories of fish. Estuar Coast Shelf Sci 66:147-156

Farrell J, Campana SE (1996) Regulation of calcium and strontium deposition on the otoliths of juvenile tilapia, Oreochromis niloticus. Comp Biochem Physiol 115: 103-109

Gibson-Reinemer DK, Johnson BM, Martinez PJ, Winkelman DL, Koenig AE, Woodhead JD (2009) Elemental signatures in otoliths of hatchery rainbow trout (Oncorhynchus mykiss): distinctiveness and utility for detecting origins and movement. Can J Fish Aquat Sci 66:513-524

Gillanders BM (2005) Otolith chemistry to determine movements of diadromous and freshwater fish. Aquat Living Resour 18:291-300

Hale R, Swearer SE (2008) Otolith microstructural and microchemical changes associated with settlement in the diadromous fish Galaxias maculatus. Mar Ecol Prog Ser 354: $229-234$

> Harris JH (1986) Reproduction of the Australian bass, Macquaria novemaculeata (Perciformes: Percichthyidae) in the Sydney Basin. Aust J Mar Freshw Res 37:209-235

Herrera M, Vargus-Chacoff L, Hachero I, Ruíz-Jarabo I, Rodiles A, Navas JI, Manchera JM (2009) Osmoregulatory changes in wedge sole (Dicologoglossa cuneata Moreau, 
1881) after acclimation to different environmental salinities. Aquac Res 40:762-771

Hindell JS, Jenkins GP, Womersley B (2008) Habitat utilisation and movement of black bream Acanthopagrus butcheri (Sparidae) in an Australian estuary. Mar Ecol Prog Ser 366:219-229

> Jensen MK, Madsen SS, Kristiansen K (1998) Osmoregulation and salinity effects on the expression and activity of $\mathrm{Na}^{+}{ } \mathrm{K}^{+}$-ATPase in the gills of European sea bass, Dicentrarchus labrax (L.). J Exp Zool 282:290-300

Kalish JM (1989) Otolith microchemistry: validation of the effects of physiology, age, and environment on otolith composition. J Exp Mar Biol Ecol 132:151-178

Kalish JM (1991) Determinants of otolith chemistry: seasonal variation in the composition of blood plasma, endolymph and otoliths of bearded rock cod Pseudophycis barbatus. Mar Ecol Prog Ser 74:137-159

Kennedy BP, Folt CL, Blum JD, Chamberlain CP (1997) Natural isotope markers in salmon. Nature 387:766-767

Kennedy BP, Blum JD, Folt CL, Nislow KH (2000) Using natural strontium isotopic signatures as fish markers: methodology and application. Can J Fish Aquat Sci 57:2280-2292

Kerr LA, Secor DH, Kraus RT (2007) Stable isotope $\left(\delta^{13} \mathrm{C}\right.$ and $\delta^{18} \mathrm{O}$ ) and $\mathrm{Sr} / \mathrm{Ca}$ composition of otoliths as proxies for environmental salinity experienced by an estuarine fish. Mar Ecol Prog Ser 349:245-253

Kraus RT, Secor DH (2004) Incorporation of strontium into otoliths of an estuarine fish. J Exp Mar Biol Ecol 302: 85-106

Lowe MR, DeVries DR, Wright RA, Ludsin SA, Fryer BJ (2009) Coastal largemouth bass (Micropterus salmoides) movement in response to changing salinity. Can J Fish Aquat Sci 66:2174-2188

Luo J, Serafy JE, Sponaugle S, Teare PB, Kieckbusch D (2009) Movement of gray snapper Lutjanus griseus among subtropical seagrass, mangrove, and coral reef habitats. Mar Ecol Prog Ser 380:255-269

Macdonald JI, Shelley JMG, Crook DA (2008) A method for improving the estimation of natal chemical signatures in otoliths. Trans Am Fish Soc 137:1674-1682

> Martin GB, Thorrold SR (2005) Temperature and salinity effects on magnesium, manganese, and barium incorporation in otoliths of larval and early juvenile spot Leiostomus xanthurus. Mar Ecol Prog Ser 293:223-232

Martin GB, Wuenschel MJ (2006) Effect of temperature and salinity on otolith element incorporation in juvenile gray snapper Lutjanus griseus. Mar Ecol Prog Ser 324: 229-239

Martin GB, Thorrold SR, Jones CM (2004) Temperature and salinity effects on strontium incorporation in otoliths of larval spot (Leiostomus xanthurus). Can J Fish Aquat Sci 61:34-42

McCulloch M, Cappo M, Aumend J, Müller W (2005) Tracing the life history of individual barramundi using laser ablation MC-ICP-MS Sr-isotopic and Sr:Ba ratios in otoliths. Mar Freshw Res 56:637-644

- Melancon S, Fryer BJ, Gagnon JE, Ludsin SA (2008) Mineralogical approaches to the study of biomineralization in fish otoliths. Mineral Mag 72:627-637

Melancon S, Fryer BJ, Markham JL (2009) Chemical analysis of endolymph and the growing otolith: fractionation of metals in freshwater fish species. Environ Toxicol Chem 28:1279-1287

> Miller JA (2009) The effects of temperature and water concentration on the otolith incorporation of barium and manganese in black rockfish Sebastes melanops. J Fish Biol $75: 39-60$
Milton DA, Chenery SR (2005) Movement patterns of barramundi Lates calcarifer, inferred from ${ }^{87} \mathrm{Sr} /{ }^{86} \mathrm{Sr}$ and $\mathrm{Sr} / \mathrm{Ca}$ ratios in otoliths, indicate non-participation in spawning. Mar Ecol Prog Ser 301:279-291

- Milton D, Halliday I, Sellin M, Marsh R, Staunton-Smith J, Woodhead J (2008) The effect of habitat and environmental history on otolith chemistry of barramundi Lates calcarifer in estuarine populations of a regulated tropical river. Estuar Coast Shelf Sci 78:301-315

Morse JW, Bender ML (1990) Partition coefficients in calcite: examination of factors influencing the validity of experimental results and their application to natural systems. Chem Geol 82:265-277

- Nicholson G, Jenkins GP, Sherwood J, Longmore A (2008) Physical environmental conditions, spawning and earlylife stages of an estuarine fish: climate change implications for recruitment in intermittently open estuaries. Mar Freshw Res 59:735-749

Olsson PE, Kling P, Hogstrand C (1998) Mechanisms of heavy metal accumulation and toxicity in fish. In: Langston WJ, Bebianno MJ (eds) Metal metabolism in aquatic environments. Chapman \& Hall, London, p 321-350

Payan P, Edeyer A, de Pontual H, Borelli G, Boeuf G, MayerGostan N (1999) Chemical composition of saccular endolymph and otolith in fish inner ear: lack of spatial uniformity. Am J Physiol Regul Integr Comp Physiol 277: 123-131

Payan P, Borelli G, Priouzeau F, de Pontual H, Boeuf G, MayerGostan N (2002) Otolith growth in trout Oncorhynchus mykiss: supply of $\mathrm{Ca}^{2+}$ and $\mathrm{Sr}^{2+}$ to the saccular endolymph. J Exp Biol 205:2687-2695

> Ruttenberg BI, Hamilton SL, Hickford MJH, Paradis GL and others (2005) Elevated levels of trace elements in cores of otoliths and their potential for use as natural tags. Mar Ecol Prog Ser 297:273-281

> Sadovy Y, Severin K (1994) Elemental patterns in red hind (Epinephalus guttatus) otoliths from Bermuda and Puerto Rico reflect growth rate not temperature. Can J Fish Aquat Sci 51:133-141

> Secor DH, Rooker JR (2000) Is otolith strontium a useful scalar of life cycles in estuarine fishes? Fish Res 46:359-371

Sinclair DJ, Kinsley LPJ, McCulloch MT (1998) High resolution analysis of trace elements in corals by laser ablation ICP-MS. Geochim Cosmochim Acta 62:1889-1901

- Swearer SE, Caselle JE, Lea DW, Warner RR (1999) Larval retention and recruitment in an island population of a coral-reef fish. Nature 402:799-802

Trnski T, Hay AC, Fielder DS (2005) Larval development of estuary perch (Macquaria colonorum) and Australian bass ( $M$. novemaculeata) (Perciformes: Percichthyidae), and comments on their life history. Fish Bull 103: 183-194

Turner DR, Whitfield M, Dickson AG (1981) The equilibrium speciation of dissolved components in freshwater and seawater at $25^{\circ} \mathrm{C}$ and $1 \mathrm{~atm}$ pressure. Geochim Cosmochim Acta 45:855-881

> van der Wal E (1985) Effects of temperature and salinity on the hatch rate and survival of Australian bass (Macquaria novemaculeata) eggs and yolk-sac larvae. Aquaculture 47:239-244

- Walther BD, Thorrold SR (2006) Water, not food, contributes the majority of strontium and barium deposited in the otoliths of a marine fish. Mar Ecol Prog Ser 311:125-130

> Weber PK, Hutcheon ID, McKeegan KD, Ingram BL (2002) Otolith sulfur isotope method to reconstruct salmon (OnCorhynchus tshawytscha) life history. Can J Fish Aquat Sci 59:587-591 
Weidel BC, Ushikub T, Carpenter SR, Kita NT and others (2007) Diary of a bluegill (Lepomis marcrochirus): daily $\delta^{13} \mathrm{C}$ and $\delta^{18} \mathrm{O}$ records in otoliths by ion microprobe. Can J Fish Aquat Sci 64:1641-1645

Wells BK, Rieman BE, Clayton JL, Horan DL, Jones CM (2003) Relationships between water, otolith, and scale chemistries of westslope cutthroat trout from the Coeur d'Alene River, Idaho: the potential application of hard-part chemistry to describe movements in freshwater. Trans Am Fish Soc 132:409-424

Editorial responsibility: Ivan Nagelkerken, Nijmegen, Netherlands
Whitledge GW, Johnson BM, Martinez PJ (2006) Stable hydrogen isotopic composition of fish reflects that of their environment. Can J Fish Aquat Sci 63:1746-1751

> Zimmerman CE (2005) Relationship of otolith strontium-tocalcium ratios and salinity: experimental validation for juvenile salmonids. Can J Fish Aquat Sci 62:88-97

Zwolsman JJG, van Eck GTM (1999) Geochemistry of major elements and trace metals in suspended matter of the Scheldt estuary, southwest Netherlands. Mar Chem 66: 91-11

Submitted: February 11, 2010; Accepted: June 13, 2010

Proofs received from author(s): August 18, 2010 